\title{
The Fan Use of Football Club Official Media (Descriptive Study of The Use of PS Sleman Official Media)
}

\author{
Narayana Mahendra Prastya ${ }^{1, a)}$ \\ ${ }^{1}$ Universitas Islam Indonesia, Yogyakarta, Indonesia \\ a) author correspondence : narayana@uii.ac.id
}

DOI: https://doi.org/10.18196/jkm.121033

Article Info

Article history:

Received 1 Feb 2020

Revised 17 Apr 2020

Accepted 5 May 2020

\section{ABSTRACT}

This research analyzed the use of official media of the Indonesia football club used by the fans. The context of official media is the official club website and official social media account of the club. The football club needs to manage the official media (especially in the internet platform) to build interaction and relationships with its fans. An engaging interaction and relationship with fans will strengthen the fans' loyalty to the club. This research used qualitative methods, with an interview in Focus Group Discussion (FGD) format as the data collecting technique. The informants were the university student aged 18-21 years old and the fans of PS Sleman (written with PSS hereafter) football club. The number of participants was eight. FGD held in May 2017, when in that year, PSS became the only Liga 2 contestant that had a verified Twitter account. Results showed that although the informants used the PSS official media, they were unsatisfied because the PSS official media lacked interactivity, updating information, and the completeness of the information. To fulfill their expectations, informants use the unofficial media, usually the fans-driven media. For informants, the unofficial media performance was much more significant than the PSS official media

Keywords: Fans; Media Usage; Organization Official Media; PS Sleman; Sport Communication

\section{ABSTRAK}

Penelitian ini bertujuan untuk mengetahui bagaimana pengunaan media resmi klub sepakbola oleh fans sepakbola di Indonesia. Batasan dari media resmi adalah website resmi dan akun resmi media sosial klub sepakbola. Di era internet seperti saat ini, penting bagi sebuah klub sepakbola untuk mengelola media resmi yang berbasis internet guna membangun interaksi dan relasi dengan fans. Dengan begitu, loyalitas fans terhadap klub dapat semakin kuat. Sumber data penelitian ini adalah fans dari klub sepakbola PS Sleman (PSS). Penelitian menggunakan metode kualitatif dengan teknik pengumpulan data berupa wawancara dalam kegiatan Focus Group Discussion (FGD). Sumber data adalah informan yang berjumlah delapan orang dengan latar belakang mahasiswa usia 18-21 tahun. Pengambilan data dilakukan pada Mei 2017, di mana di tahun tersebut PSS menjadi klub kontestan Liga 2 Indonesia yang memiliki akun twitter yang sudah terverifikasi. Hasil penelitian menunjukkan bahwa mayoritas dari informan mengatakan kurang puas dengan performa media resmi PSS karena kurang dari segi interaktivitas, pembaruan informasi, dan kelengkapan informasi. Guna memenuhi rasa ingin tahu mereka, infoman menjadikan akun komunitas suporter sebagai rujukan informasi tentang PSS. Informan mengatakan bahwa kualitas akun tidak resmi itu justru lebih baik daripada media resmi PSS.

Kata Kunci: Fans; Komunikasi Olahraga; Penggunaan Media; Media Resmi Organisasi; PS Sleman 


\section{INTRODUCTION}

Official media, especially the internet-based media such as official website and official social media account, is essential for football clubs. By using official media, a football club can take many advantages. Football clubs have been using new media for publicity, advertisement, marketing activities receiving feedbacks from target-groups about brand image, corporate reputation, organizational culture or products and services, as a direct channel for accessing their fans and providing them with the necessary information. This process allows fans with online capabilities to access up-to-date information by accessing the official club website (Cleland, 2011; Goksel et al., 2015).

An increasing number of professional sports leagues are relying on the internet, social networking sites, and mobile technologies to market their team, citing it as a cost-effective avenue for reaching a larger audience of sports fans - or consumers. The internet enriches the sport experience through in-depth product (team-related) information, venue information and interactive experiences (Da Sliva, 2017)

The public relations (PR) of sports clubs (in general) should work with new media and especially social media. This activity includes responsibility for running the website and updating it, establishing intelligent management of social media, and making their use effective (Tamir et al., 2015) The presence of internet gives more "pressure" toward the public relations or communication division in the football club. Social media renders intra-club communication effective and provides clubs with a direct chance to communicate with target-groups. However, on the other hand, it sometimes may also lead to a possible crisis occurring due to quick and easy spreading speculations, false news, and bias information (Goksel et al., 2015).

The performance of club official media is being criticized because the information of club official media sometimes is dishonest. The information that is harmful to the club's interest is not published. The official club website just contains "standard" information, such as updating player injury and squad list. There has been no critical information, such as the player salary or contract value. (Rahman, 2018)

This paper aims to describe how the fans use the club's official media to fulfill their needs for information. The data was gained from the focus group discussion with PS Sleman (write with PSS hereafter). A study about how fans use the club official media is relatively rare because what have mainly explored is how sports organizations and professional athletes managed their social media (Vale and Fernandes, 2017).

However, some international research has discussed how fans use the club official media. In England, football fans used the mainstream media (e.g., local newspaper) as the first information source, meanwhile club official websites accounted for the second position. Nevertheless, Northampton Town fans used the official club website because football is not a popular sport, and local newspaper prefers to coverage the rugby team (Cleland). It is worth noting that this research held ten years ago.

Another research in England towards Newcastle United fans shows the Newscastle fans were not fully satisfied with the content that the club provides on social media. They felt that the club's social media did not provide engaging content. The fans that were interviewed, in different terms, described Newcastle United's social media efforts as "poor," "sterile," "terrible," "It is kind of dead," or at best as "OK." None of the persons interviewed found that the club was doing a decidedly good job operating its social media sites (Sigurdsson, 2019)

In Turkey, the presence of the internet and social media has given an advantage for unpopular sport. Sports fans share events about amateur branches on new media settings, such as social networks. Thus, sports news which is not given in mainstream media like newspaper and television is circulated on social networks (Ozsoy, 2011). In the United States of America (USA), sports fans used Social Networking Sites (SNS) to enhance the online experience for sports fans, giving them an additional way in which to connect to their community, make new friends and forge weak ties, and to an extent, maintain existing close emotional bonds and relationships (Phua, 2012)

To summed up the previous research, the internet has changed the way people communicate. The internet influences the need for communication in modern society, as interactive communication, and many to many communication become important. Additionally, the internet gives individual/user many choices to information sources, and the user can express their own view/opinion (Nurudin, 2013; Pratiwi, 2014; Sukowati, 2019). 
In the football context, fans now can search for information from the unofficial sources such as community media (fan-driven media), rather than access the club official media, because the community media offers the possibility for fans for information sharing. Club official media, therefore, should compete with community media (Junaedi and Arifianto, 2017). For example, the unofficial sites of Newcastle United appeared to be more productive in providing fans with information about the players and general club proceedings, yet, at the same time fans talk about the importance of "credibility" and how there needs to be a trust in the information that is being provided. The communication in this emotionally driven context abides in a vast ambiguous yet accessible area (Sigurdsson, 2019).

Being a sports fan is an active and lived experience. Fans discuss their role because they are not just spectators; they take part in the game and believe that their presence, engagement, and involvement impact on their team's performance. Fans now can use the internet, conversation in social media, to get the information or issue, make it viral, and produce a movement. Teams, leagues, and sponsors who fail to respond to activist fan movements risk major damage to their business (Da Silva and Las Casas, 2017). For example in Indonesia, Brigata Curva Sud (the ultras from PS Sleman football club) forced their club to maximize the role of club official media for information publicity and could be the trusted information news sources for the PS Sleman fans (Irawan, 2019).

\section{METHODS}

This research used a qualitative method. For data collecting, this research used a semi-structured interview in Focus Group Discussion (FGD) format. The profile of the informants were: (1) PSS football fans; (2) university students; and (3) aged between 18-21 years old (when FGD was held, mid-May 2017). There were 8 (eight) informants in this FGD. The identity of the informant, see Table 1 below.

Table 1. List of Informants

\begin{tabular}{ccc}
\hline Informant Number & Name & Age (in time when the interview was held) \\
\hline Informant 1 & Khalif Madani & 19 years old \\
Informant 2 & Marvindo Dwi Putra & 20 years old \\
Informant 3 & Tofan A. Maulana & 20 years old \\
Informant 4 & Rifki A. Nurfauzi & 21 years old \\
Informant 5 & Mohammad R. Emir & 20 years old \\
Informant 6 & Damar Aziz P & 20 years old \\
Informant 7 & Mahmud Tri Y & 20 years old \\
Informant 8 & M. Naufal Alfareza & 18 years old \\
\hline
\end{tabular}

There are several reasons for the time frame and the informant selection. First, in 2017 PSS was the only club in Liga 2 (the second tier of Indonesian football competition) that has verified account on its Twitter. It indicates the seriousness of PSS management in developing its internet-based official media (Al Isamer, 2019). PSS promoted to Liga 1 [the first tier of Indonesian football competition] after winning the Liga 2 season 2018. PSS or so-called the "Super Elang Jawa" has participated in Liga 1 since 2019).

Second, the reason to choose informants is the data about the internet user. Almost $50 \%$ of internet users aged 18-25 and nearly 90\% of internet users have an educational background from senior high school and upward. Based on the profession, the university students lay in second place (18\%), behind the employee (55\%) as the most internet user (Sukowati, 2019)

In particular, sports fans that have a college student background assumed to be more mature than common fans because they have a higher educational level (Prakoso, 2013; Sunaryadi et al. 2010). Research about how sports fans with college student background showed that the fans in the research followed sports news on Facebook as frequently as they followed the sports news on the Internet. This research held in Turkey (Ozsoy, 2011)

Third, related to the methods, this research adopted the data collecting technique from Lindawati (2015) that used the in-depth interview to 6 (six) internet user from the young age with different demographic status (education background, economic, and residence) to get the detail information about how they use online news media. The limitation of the research used FGD as the data. It is 
different from Lindawati (2015) that continued her research with quantitative methods with an online survey as the data collecting technique.

\section{RESULT AND DISCUSSION}

This section has two main points. The first is to show the results containing the wrap up from the focus group discussion (FGD) with eight informants. The informants were university students. In the PSS fan community, the fans that have background university students usually joined in a group named Campus Boys 1976. This community has several chapters based on the campus.

The theme of FGD was fan's opinion about the PSS official media (website and social media). Talking about the PSS official website, the informants said they relatively rare to access it because the website was quite difficult to access. The informant said that they should open the browser, type the website address, to open it, and according to them, it was quite challenging to do. To gain information about PSS, they waited for the social media buzz. For the wrap up for each participant, see table 2.

Table 2. The use of the Internet for information searching related to PS Sleman

\begin{tabular}{|c|c|}
\hline Participants $(\mathrm{P})$ & Statement \\
\hline P1 & $\begin{array}{l}\text { I often access the official Instagram of PSS, because it is easy to open from my } \\
\text { mobile phone. The information also appears in the timeline. Information from the } \\
\text { official IG of PSS is mostly about the team condition, the opponent, and the } \\
\text { match schedule. PSS information is less-varied if I compare to Sleman Footbal } \\
\text { and BCS because both accounts offer information about what the player does, } \\
\text { and we like it. }\end{array}$ \\
\hline $\mathrm{P} 2$ & $\begin{array}{l}\text { I usually access Instagram and Twitter. However, I often open twitter because if } \\
\text { you do not see the match, or are away from it, sometimes there is a direct tweet, } \\
\text { so the information obtained is more frequent. Compared to Instagram, Twitter's } \\
\text { information is disseminated more quickly. }\end{array}$ \\
\hline P3 & $\begin{array}{l}\text { I often visit the PSS official website, pss-sleman.co.id. I think the visual design is } \\
\text { attractive, but the information is not updated. The update information only } \\
\text { appears a day after a match. Slemanfotball is interesting because it updates } \\
\text { match, the technical information, the tips for Sleman supporter to trip to the } \\
\text { opponent's stadium, and the story behind awaydays }\end{array}$ \\
\hline P4 & $\begin{array}{l}\text { I think the Instagram of PSS is less interesting because sometimes the feed is } \\
\text { chaotic. For twitter itself, PSS Sleman's Twitter contains information about } \\
\text { preparation, or before the game. However, for more detailed information, it even } \\
\text { goes to an account such as BCSxPSS. For example info for us when we go to the } \\
\text { opponent's stadium, the obstacle that might appear when we are coming back for } \\
\text { home, or ticket information }\end{array}$ \\
\hline P5 & $\begin{array}{l}\text { I rarely visit the official media of PSS. I usually search for information about } \\
\text { after match because of many interesting things. In addition, before the PSS away } \\
\text { match, I look for information about the time, how to get there, how the } \\
\text { relationship between PSS fans and the home fans, and whether we get permission } \\
\text { or not }\end{array}$ \\
\hline P6 & $\begin{array}{l}\text { For myself, I prefer to access Sleman Football. I use social media like Twitter or } \\
\text { Instagram because I can get the information directly, faster, and more } \\
\text { comfortable than the official website. }\end{array}$ \\
\hline P7 & $\begin{array}{l}\text { I prefer to access Official Instagram and Twitter of PSS. I like the photos of team } \\
\text { arrival and aftermatch posted on PSS Instagram. For Twitter, I use it for } \\
\text { information update about the match, read the live-tweet when I cannot go to the } \\
\text { stadium or when the television does not air the PSS match. Meanwhile, I often }\end{array}$ \\
\hline
\end{tabular}


access Sleman football, too, for references. This media is more interesting than the official because a lot more animation and the content can educate the PSS fans.

I follow social media; it is more like Instagram on PSS club twitter. In my opinion, if the Sleman PSS tweet, it might be because it is more critical information about the PSS. Sometimes the ones on Instagram are only a matter of match info, technical meeting photos

Informants also gave their advice and critics to PSS official website content that still less up to date. One informant said PSS official website published information about the news match, one day after the match. Meanwhile, fans need immediate news and information since the fans need news faster. Another informant thought the information on PSS official website was not suitable to accommodate his needs. For the wrap up for each participant, see table 3.

Table 3. The Advice and Critics for the PSS Official Account

\begin{tabular}{|c|c|}
\hline Participants $(\mathrm{P})$ & Statement \\
\hline P1 & $\begin{array}{l}\text { What is happening in PSS now seems like there are two official accounts. Sleman } \\
\text { Football is an unofficial account, but their information is like an official account } \\
\text { because it contains much information, up to date. I think PSS should manage } \\
\text { their official account like what European team do. For example, in Manchester } \\
\text { United official account, there are statistics...everything is there. Although MU's } \\
\text { unofficial accounts are uploaded the same information, we know that this is an } \\
\text { official account. If we open it, we will get all kinds of information about MU } \\
\text { from the official account }\end{array}$ \\
\hline $\mathrm{P} 2$ & $\begin{array}{l}\text { PSS official account provides good visualization. The interactivity is not } \\
\text { optimum, but I think it is better because if the PSS official account is too } \\
\text { talkative, it will be counter-productive and makes a fuss for fans. }\end{array}$ \\
\hline P3 & $\begin{array}{l}\text { I think official accounts have to keep their distance from supporters, so they do } \\
\text { not interact too much with netizens. However, I feel, somehow, the distance is } \\
\text { too far. As an official account, PSS should imitate what Sleman Football does, } \\
\text { like providing match statistics and information. }\end{array}$ \\
\hline P4 & $\begin{array}{l}\text { I think interaction is very lack. It is just possible because it is an official account, } \\
\text { so this admin must be careful, do not let it backfire on the PSS itself. Simply put, } \\
\text { it might be like that. Because it is official, so you have to be careful, not just } \\
\text { mention it }\end{array}$ \\
\hline P5 & $\begin{array}{l}\text { In my opinion, the quality of photos and videos provided by PSS official media is } \\
\text { good. For example, photos in team launching. A few days ago, I saw, although, } \\
\text { like every moment, a photo. It was issued a quality photo, not only the photos for } \\
\text { internal documentation. So it seems that the photos were not arbitrarily derived } \\
\text { from the documentation, but people can show that the results are excellent and } \\
\text { best. }\end{array}$ \\
\hline P6 & $\begin{array}{l}\text { The interaction is lack, but my experience, if I ask about something very urgent } \\
\text { to be discussed with fans, the PSS official account usually replied. However, } \\
\text { when there is a mention from fans another club with a challenging tone, the } \\
\text { official account tends to ignore it. I think the official account should limit their } \\
\text { interactions, especially with fans from another team }\end{array}$ \\
\hline P7 & $\begin{array}{l}\text { My opinion about the official PSS account is good when it comes to photos. } \\
\text { Similarly, the PSS video is good. It can print media compared to other teams. } \\
\text { However, on Twitter, if we ask it is rarely answered unless we ask important } \\
\text { questions. }\end{array}$ \\
\hline
\end{tabular}



less communicative, so Sleman fans. Yes, there may be interactions, but rarely. So there is a gap between fans and clubs

To sum up, all informants said that they used the unofficial website (managed by the initiative of PSS fans or official websites and social media from fans community) as their primary source. According to the informants' opinion, this unofficial website provides better, more updated, and more varied information compared to PSS official website. This is also the reason for the informant to be more frequent and more attracted to websites built by supporters of the PSS itself.

Informants also shared their hope to PSS official website. They wanted PSS can accommodate all of the information they are looking for, which contains not only info about the team internal, but also the overall information that gives benefit to the fans. They also wanted the PSS to give the fans to contribute to content making. Informants assumed this way would bring a good relationship between fans and the club.

Informants then gave their view about the interactivity of the PSS website. Informants said the PSS website communication pattern was one way and did not provide a special page or special feature to facilitate the interaction between the fans/website visitor with the website administrator. PSS website also did not provide the feature for the visitors, such as the comment page toward the news or information.

There were two different opinions from the informants about the interactivity of the PSS official website. On one side, the lack of interactivity in the PSS official website made the informants preferred to visit the unofficial because they assumed that these accounts were much more responsive, and no impression stiffness in the accounts, compared with PSS official website that was too rigid, or for those too formal. On the other hand, informants assumed the lack of interactivity was caused by PSS policy in order to keep the club credibility and just shared the valid information and did not respond to the unconfirmed mentions.

Besides the website, the informants also opined about how they used social media (Twitter and Instagram) to gain information about PSS. Informants said the PSS social media account was still too formal, somehow being rigid, and less attractive compared to the unofficial social media account. The source also said that the content presented by social media PSS was incomplete. One informant also gave his comments about the visual display that made him confused.

When asked their comments about the interactivity of PSS official social media, the informants' answers was quite the same with the website. There was not much interaction between the official account with the fans. Similar to the website, the PSS official social media mostly only provided information to fans and not made interaction.

PSS only occasionally responded to the mention that came to them. For example, on Twitter, sometimes the account gave a reply to the followers who gave a mention to @PSSleman. However, the reply tended only to accounts with technical problem question, a technical clarification, or simply retweet to the accounts instead of a personal tweet about the spirit of the message.

Informant considered the interactivity on Twitter@PSSleman very poor, and it seems to make the distance between the fans of the club. Lack of enough 2-way interaction of official account is also likely to make the fans agreed that they often opened accounts of supporters because they were closer to them, and were considered more responsive and more interactive than the official account of the PSS. This condition made the informants said they enjoyed searching for information about PSS and interact on an unofficial social media account. Even as on the website, informants headed to the unofficial account as their primary reference in information searching.

As the final words of the FGD, informants shared their hope about official club media should be the primary information sources/references for the fans. Nevertheless, the PSS official media was unable to fulfill the need of the fans. According to informants, their needs were accommodated by the unofficial account. It made the unofficial account look like the official media account, due to the completeness of the information.

The second section of this part is the discussion. From the FGD, informants said that they relatively did not satisfied with the performance of PSS official media, both the website and social media. Although the FGD (as the data for this research) was held in 2017, the dissatisfaction still exists until (at least) 2019 when PSS fans (from the BCS community) pointed out the improvement of 
PSS official media performance as the one of eight BCS demands to PSS management to improve the club professionalism aspects. (Irawan, 2019).

The disappointment from the informants that were caused by the PSS official media failed to provide the contents and communication patterns that fitted them. The informants needed interactivity. These findings are the same as the research held by Sigurdsson (2019) about how Newcastle United fans use the club's official media. The fans said the performance of the club's social media was poor.

The club should understand that nowadays, fans are not passive. Fans could comment, discuss, criticize, and even make a movement towards the club's decision. As Da Silva and Las Casas (2017) wrote, being a sports fan is an active and lived experience. Fans discuss their role because they are not just spectators. They take part in the game and believe that their presence, engagement, and involvement impact on their team's performance. Empowered by social media, fans now expect an unprecedented level of access to players, coaches, and owners.

What is more, they expected to be part of decisions that were once made behind closed doors. Besides, fans have increasingly used their collective power to influence leagues and franchises. With access to multiple Twitter feeds and other sources of information, fans not only have more power but more potential points of conflict and disgruntlement. What might set them on the warpath will become increasingly difficult to predict. A team's financial decisions, broadcast blackouts, rule changes, trades, or off-field behavior may spark outrage. Social media can rekindle and give new life to long-simmering disputes.

Nearly a decade ago, Cleland (2011) had predicted the presence of social media, and the internet would bring the new challenge to club management. One of the most significant changes in this relationship occurred when the 'new' media not only provided an increasing amount of coverage on the game but also helped to create a two-way dialogue with many 'active' supporters.

In general, the internet gives opportunities for an individual (as a user) to search, share, produce, and re-produce information that suits his/her needs. According to Pratiwi (2014), the internet gives users more choices to gain information. The Internet has changed the passive audience to become active users. A user could also add his/her opinion by commenting on the information.

In this internet era, people demand interactive and two-way communication, also many to many (Nurudin, 2013). In the football context, Vale and Fernandes (2017) said football clubs should enable fan expression, through discussion boards and walls used for dialogue between the sports organization and fans. Sports organizations may also solicit inputs, e.g., allowing fans to personalize team products or to provide inputs on the future direction of the club. Research from Goksel et al. (2015) explained how communication officers from three clubs in Turkey used the club's official social media to build a good relationship with the fans. In general, the clubs always gave attention to the expectations, wishes, critics, and complaints from mention, reply, or message delivered by the fans to the club official account. An informant from one club said that the communication officer also tried to communicate the fans' advice to the related department in the club if it was required. Another informant sometimes said the club official social media post the informal message such as greetings to its fans.

The statement from the previous paragraphs would be very helpful if Indonesian football clubs can practice it. Nevertheless, how did the Indonesian football clubs manage their official media (especially the internet-based media)? Anshari and Akbar (2019) explained three management of sport communication in Indonesian football clubs: (1) the active interactions, (2) passive interactions, and (3) no interactions at all. Comparing with the finding of the research, PSS used the latest model. According to Anshari and Akbar (2019), in this model, the clubs just use their official media to post the updated information with no effort to answer the question or mention from the followers. The purpose of this model is, first, to prevent reply or post that out of context because of provocative mentions that may come and, second, to keep their credibility with this "classy" strategies.

The "no interactions at all" seems not to fit the needs of fans. In general public relations practices, the presence and development of the internet have influenced the practice of public relations activities of organizations, as Arief (2019) wrote nowadays PR 2.0 and PR 3.0 become the standard practice. The characteristic of PR 2.0 are horizontal communications, connected, and many-to-many. In PR 2.0, the public relations officer role becomes the connector between organizations and their publics. The characteristic of PR 3.0 is social media become the most used, most liked, and getting more trust from the public, so public relations officers should monitoring the issue in social media while still monitoring the traditional media. 
Connecting with the public also become the task for public relations or communication officer in a sports club. One of the influential public for sports club are fans. Tamir et al. (2015) stated that sport public relations should build a good relationship with fan organizations. Fans described as not only the financial backbone of every sports team. They are also its heart and engine. Like any heart-they are full of positive and negative emotions. They are not only fans but also lovers (of players, coaches, managers, and owners) and sometimes haters. Their emotional moods are often directed toward semipractical efforts: demands that managers and owners resign, that a coach is dismissed, that certain players are chosen for the opening play.

Based on the finding of the research, the informants looked for other sources to fulfill their needs. The informants were the young people that tend to compare the information by using several internet sources. It supports the Lindawati (2015) research result about how young people use 3-4 online news sources to get enough knowledge about a particular issue. Informants said that their reason to check unofficial media was driven by the fan community to fulfill their needs and expectation, namely searching for information about their favorites clubs, share it, and interact with another user. According to Junaedi and Arifianto (2017), the presence of fans-based media should be a critic for football club management. By using the fans-based media, fans enable to participate in information sharing about the club. Meanwhile, several clubs still rarely managed their official media.

Although the unofficial media could fulfill the fans' expectations, it is worth noting for the fans to keep critical on it because internet users just pay attention to the content. Rianto (2016) highlighted that the internet user just chooses the information that supports their views, and share it. Internet users sometimes do not care about the sources' credibility and information accuracy.

In the football context, unofficial media have handicap related to content quality, information credibility, and human resources. The content just shows support, somehow glorified, and show positive images for the club. Although the unofficial media managed by fans (it means, outside from the club management structure), it rarely gives critics to the club. From human resources aspects, they are lack of journalism skill to do investigative reporting (Rahman, 2018; see also Sigurdsson, 2019).

\section{CONCLUSION}

The informants said they relatively rare to access the official media of PSS, both for the official website and official social media account. The general reason is that the PSS official media was lack of interactivity, the content is not up-to-date, and the website is difficult to access. In general, all informants said that they use the unofficial website and social media, managed by the fans (outside the club management) as their primary source. The reason is that these unofficial media perform better than the PSS official media. Finally, informants shared their hope about official club media should be the primary information sources/references for the fans. They expected PSS could provide the information that suits to the fans' needs. They also wanted the PSS to give opportunities to the fans to contribute to the content making.

For recommendations, further research can consider these considerations. First, because this research just early findings and the result can not be generalized, a survey method (as worked by Lindawati, 2015; Ozsoy, 2011; Phua, 2012; Sigurdson, 2019; Vale and Fernandes, 2017) in order to get broader context is preferred. Second, because different backgrounds of the participants may lead to different results of detail, expanding the background of the informant or responded as the data resource (e.g., based on sex, different university, educational background, occupation) for the next research can complete the understanding of this topic. Third, the data collection process was conducted in 2017, the moment when PSS became the only Liga 2 contestant that has verified account on its Twitter. In the three years, many changes have taken place. The current research has shown that PSS used active interactions as their official media communication strategy (Anshari and Akbar, 2019). Further research can measure how the fan uses the PSS official media. It is also possible for research with different fans from different football clubs. 


\section{REFERENCES}

Al Ismaer, M. (2019). Cyber Public Relations di Klub Sepakbola PSS Sleman (tahun 2016-2017)" Humas Dalam Organisasi Olahraga: Konsep Dan Aplikasi. (Editor : Narayana Mahendra Prastya). Yogyakarta : Penerbit Komunikasi UII.

Anshari, F., \& Qalbie Septizar Akbar, F. (2019). Analisis Model Pengelolaan Platform New Media Oleh Klub Sepakbola di Indonesia. CoverAge: Journal of Strategic Communication, 10(1), 8-18. https://doi.org/10.35814/coverage.v10i1.1228

Arief, N. (2019). Public Relations in The Era of Artificial Intelligence. Bandung: Simbiosa Rekatama Media.

Cleland, J. (2011). The media and football supporters: A changing relationship. Media, Culture and Society, 33(2), 299-315. https://doi.org/10.1177/0163443710393866

Da Silva, E. C \& Las Casas, A.L. (2017). Sports Fans as Consumers: An Apprach to Sport Marketing. British Journal of Marketing Studies, 5(4), 34-46. https://doi.org/10.1017/CBO9781107415324.004

Gürel Göksel, A., Ali Gürel Göksel, C., \& Zahit Serarslan, M. (2015). Public relations in sports clubs: New media as a strategic corporate communication instrument. International Journal of Physical Education, Sports and Health IJPESH, 2(2), 275-283.

Irawan, A. (2019). Mewujudkan PSS menjadi Klub Profesional. Merawat Sepakbola Indonesia. (Editors : Sirajudin Hasbi and Moddie A. Wicaksono). Yogyakarta : Fandom Indonesia.

Junaedi, F., \& Arifianto, B. (2017). Berawal dari Kecintaan, Berproses dalam Media Komunitas : Menengok Manajemen Media Berbasis Fans Sepakbola. Mediamorfosa: Transformasi Media Komunikasi Di Indonesia. (Editor : Fajar Junaedi). Yogyakarta : Penerbit Buku Litera.

Lindawati, L. (2015). Pola Akses Berita Online Kaum Muda. Jurnal Studi Pemuda, 4(1), 241-259.

Nurudin. (2013). Media Sosial Baru dan Munculnya Revolusi Proses Komunikasi. Jurnal Komunikator, 5(2), 83-93.

Özsoy, S. (2011). Use of new media by Turkish fans in sport communication: Facebook and Twitter. Ovidius University Annals, Series Physical Education and Sport, 11(2), 591-598. https://doi.org/10.2478/v10078-011-0033-x

Phua, J. (2012). Use of Social Networking Sites by Sports Fans: Implications for the Creation and Maintenance of Social Capital. Journal of Sports Media, 7(1), 109-132. https://doi.org/10.1353/jsm.2012.0006

Prakoso, S. A. (2013). Fanatisme Suporter Sepakbola Ditinjau dari Tingkat Pendidikan. Skripsi Fakultas Psikologi Universitas Muhammadiyah Surakarta.

Pratiwi, M. R. (2014). Peran ICT bagi Organisasi Media Massa dan Budaya Masyarakat. Jurnal Komunikator, 6(1), 20-26.

Rahman, F. (2018). Profesionalisme dan Transparansi Semu Sepakbola Indonesia. Sepakbola 2.0, Cetakan Kedua. (Editor : Sirajudin Hasbi dan Ferry Triadi Sasono). Yogyakarta : Fandom Indonesia.

Rianto, P. (2016). MEDIA BARU, VISI KHALAYAK AKTIF DAN URGENSI LITERASI MEDIA. Jurnal Komunikasi Ikatan Sarjana Komunikasi Indonesia, 1(2), 90-96. https://doi.org/10.25008/jkiski.v1i2.54

Sigurdsson, A. (2019). Football Clubs Uses Of Social Media: A Case Study of Newcastle United FC From A Fan Perspective. Master Thesis Department of Communication Lund University.

Sokowati, M. E. (2019). Questioning Public Participation in Social Media Activities in Indonesia. Komunikator, 11(2). https://doi.org/10.18196/jkm.112025

Sunaryadi, Y., Uw, L., \& Suntoda, A. (2010). Analisis Perilaku Kekerasan Penonton Sepakbola. Makalah Seminar Jurusan Pendidikan Dan Kepelatihan, Fakultas Pendidikan Olahraga Dan Kesehatan. Bandung: Universitas Pendidikan Indonesia

Tamir, I., Limor, Y. H., \& Galily, Y. (2015). Sports: Faster, higher, stronger, and public relations. Human Affairs, 25(1), 93-109. https://doi.org/10.1515/humaff-2015-0008

Vale, L., \& Fernandes, T. (2017). Social media and sports: driving fan engagement with football clubs on Facebook. Journal of Strategic Marketing, 26(1), 37-55. https://doi.org/10.1080/0965254X.2017.1359655 